\title{
LEGISLATION ON OVERDUE PAYMENTS IN THE REPUBLIC OF MACEDONIA AND RECOMMENDATIONS FOR BUSINESS ENTITIES
}

\begin{abstract}
In the last few years, the Republic of Macedonia has adopted a number of legislative acts regulating the financial discipline of economic entities in business relations. One of the most significant new laws is the Financial Discipline Act. However, there is still a lack of specific and reliable indicators showing to what extent the economic entities doing business in the Republic of Macedonia are capable of fulfilling the obligations stipulated in this Act, which is supposed to establish order in servicing the financial obligations. We need a clearer picture of the financial condition in Macedonian companies and, of course, in the public sector. In this paper, the author analyzes the legal provisions contained in the Financial Discipline Act and some other legal solutions, in an effort to give an initial answer to the following question: Is there an economically justified financial discipline of business entities in their financial transactions in Macedonia, or is it just a tendency to establish financial discipline primarily among economic entities?! On the other hand, we will tackle certain disputable questions pertaining to the implementation of the Financial Discipline Act and particularly concerning the degree of compliance of the Macedonian law with the Directive 2011/7/EU.
\end{abstract}

Key words: financial discipline, transaction, overdue payments, autonomy of will, deadlines.

\footnotetext{
*gorgioski_orde@yahoo.com
} 


\section{Introduction}

In the last few years, the Republic of Macedonia has adopted a number of legislative acts regulating the financial discipline of economic entities in business relations. They are: the 2009 Act amending the Execution Act ${ }^{1}$; the 2012 Promissory Note Act ${ }^{2}$; the Financial Discipline Act $^{3}$, the Act amending the Promissory Note Act ${ }^{4}$, the Act on Extrajudicial settlement ${ }^{5}$, etc. These acts have primarily exerted an influence on companies in the Republic of Macedonia but they also included individuals and the public sector.

Reasons for the adoption the Financial Discipline Act primarily stem from following the developments in the European Union and the neighboring countries in terms of regulating the delay of execution of financial obligations, which includes the need to continuously take additional preventive measures to decrease the negative influence of the economic crisis on the Macedonian economy. It is a relatively new way of regulating these relations. Namely, the Directive 2011/7/EU for preventing overdue payments in business transactions was adopted in the EU as early as 2011. EU Member States transposed the Directive into their national legislations ${ }^{6}$ and some other EU membership aspiring countries $^{7}$ followed the example.

In this context, the following questions are justifiable: Does such legislative activity imply a tendency of establishing financial discipline of economic entities in business relations, and especially companies?! What is in fact financial discipline, what is its objective and can that objective be achieved by adopting the aforementioned acts? These questions are extremely important and, as such, they deserve to be answered or at least discussed in legal circles. At first, the adoption of these legal solutions was basically justified by the need to improve the financial liquidity of business subjects (mainly small and medium-size enterprises), especially in

1 Official Gazette of RM, 83/2009; the start of implementation was prolonged by the Act amending the Execution Act, Official Gazette of RM, 88/2010

2 Official Gazette of RM, 59/2012

3 Official Gazette of RM, 187/2013

4 Official Gazette of RM, 12/2014

5 Official Gazette of RM, 12/2014

6 For example, the Republic of Bulgaria adopted amendments of the Commercial Act (source: Държавен вестник“ брой: 20, от дата 28.2.2013 г.).

7 The Republic of Serbia adopted the Act on Time Limits for payment of monetary obligations in commercial transactions (Zakon o rokovima izmirenja novčanih obaveza u komercijalnim transakcijama, Službeni glasnik Republike Srbije, 119/2012). 
times of economic crisis when the access to financing sources is more difficult. Therefore, by adopting multiple legal decisions, the public authority justifies its role in terms of creating certain economic and non-economic measures for reducing the consequences of the economic crisis.

However, there is still a lack of specific and reliable indicators showing to what extent the economic entities doing business in the Republic of Macedonia are capable of fulfilling the obligations stipulated in this Act, which is supposed to establish order in servicing the financial obligations. We need a clearer picture of the financial condition in Macedonian companies and, of course, in the public sector. Namely, according to the National Bank of the Republic of Macedonia (NBRM) reports on financial stability in 2012, a claim in the corporate sector was charged within approximately 125 days, which is six days longer than in 2011 (National Bank of RM, 2012). In respect of the Financial Discipline Act, the NBRM report on financial stability in 2013 inter alia stated: "Some of the enterprises facing insufficient volume of sales, insufficient capacity for creating operative cash flows or having problems with their solvency might have difficulties adapting to the stipulations of this law" (National Bank of RM, 2013). The report also stated: "With regard to contractual maturity of corporative sector debt, long-term indebtedness was the growth carrier in 2013. Such indebtedness noted its highest absolute growth in 2013 while decreasing the shortterm indebtedness. The driving force of these movements was the indebtedness towards non-residents, where besides new long-term debt contracts there was also a transformation of the short-term ones in long-term instruments. Growth of this component of exposure is a direct consequence of difficult debt payment by the domestic enterprises. Considering the long periods of tying up funds and the modest liquidity of the domestic corporative sector, high rates of growth of nonfunctional indebtedness present another confirmation of the unequal allocation of indebtedness of the individual enterprises and for possible overindebtedness of part of domestic enterprises and the need for larger steps by banks for debt restructuring." In 2013, a corporative sector claim was on average charged within 125 days $^{8}$.

We should not forget that the preamble of the Directive 2011/7/EU ${ }^{9}$ underscores the protection of business subjects, particularly small and medium-sized business entities. The protection is twofold: (1) protection of business entities from

8 It is not clear why the Report on financial stability in the Republic of Macedonia in 2012 states that claims within the corporative sector were charged in 125 days on the average, while the Report of 2013 states that corporative sector claims in the year 2012 were charged on the average within 123 days.

9 Directive 2011/7/eu on combating late payment in commercial transactions of 16 February 2011, Official Journal of the European Union L 48/1 
other business entities, and (2) protection of business entities from public law entities (Shafranko, 2012,1231). This means that the Directive does not envisage situations when a company and a public institution are in a debtor-creditor relationship, where the company appears as a debtor of financial obligation. This part is partially included in our Financial Discipline Act, which will be subject of discussion further on in this text. Considering the development of these relations, we find that the EU provides data on average term limits in which the public sector subjects fulfill their financial obligations towards the private sector ${ }^{10}$; in Macedonia, there is no such data.

It is worth mentioning that there are difficulties in the implementation of the Directive 2011/7/EU in EU Member States, too. Namely, according to the survey of the Association of European Chambers of Commerce and Industry (Eurochambers) conducted with regard to financial obligations payment conditions in the EU public sector, Estonia and Finland are the only members of EU where public sector subjects successfully pay their debts towards private sector in less than thirty days. The top countries where public sector is quite late in servicing their financial obligations are: Italy (170 days), Greece (159 days), Spain (155 days) and Portugal (133 days). In EU, business subjects on average still wait for 61 days to get their money from public bodies.

The process of financial discipline is defined ${ }^{11}$ as: "determining of timely fulfilling of financial obligations which comes out of realization of business transactions among private sector economic operator i.e. among public sector subjects and private sector subjects for preventing unfulfilling of financial obligations within agreed terms according to this law." It can be concluded that this legal definition coincides with the Directive 2011/7/EU. But, it is very important to understand whether the new legal solutions, and particularly the Financial Discipline Act, will achieve the projected objective and anticipated results. In this paper, the author analyzes the legal provisions contained in the Financial Discipline Act and some other legal solutions, in an effort to give an initial answer to the following question: Is there an economically justified tendency of financial discipline of business entities in business transactions in Macedonia, or is it just a tendency to establish financial discipline primarily among economic entities?! On the other hand, we will tackle certain disputable questions pertaining to the implementation of the Financial Discipline Act and particularly concerning the degree of compliance of the Macedonian law with the Directive 2011/7/EU.

10 EuroChambres. Late Payment Directive six month on public payments still much too slow. Downloaded 30.01.2014. http://www.30max.eu/map-of-debtors/

11 Article 1 of Financial Discipline Act, Official Gazette of RM, 187/2013 
The Act amending the Promissory Note Act was in line with the process of financial discipline which initially stipulated the obligation for mandatory issue of promissory note in debtor-creditor relationship which created obligations in the amount of 300.000 denars and more, if legal conditions are met ${ }^{12}$. Any breach of this obligation resulted in infringements as well as criminal liability ${ }^{13}$. But, after harsh criticism towards this legal solution, the obligatory promissory note was relativised and the initial legal solution was entered into force again. Further on, the Act on Extrajudicial Settlement stipulated that in case of illiquidity ${ }^{14}$ or insolvency ${ }^{15}$, an economic operator shall not make any payments except those necessary for its regular operation; it also stipulates the obligation to initiate a procedure for extrajudicial settlement ${ }^{16}$. Any breach of obligations of this Act is regarded as infringement which implies the economic operator's liability for infringement.

\section{Disputable issues arising from the implementation of the Financial Discipline Act}

On 27.12.2013, the Assembly of the Republic of Macedonia adopted the Financial Discipline Act, which entered into force on $1^{\text {st }}$ May 2014. It is a relatively brief legal text but it is very important both for "private sector economic operators ${ }^{17}$ " and "public sector subjects" ${ }^{18}$ when acting as debtors. In the brief period of its application, there have already been certain problems in the implementation of this Act, which were underscored multiple times by the scientific public and practitioners alike.

First of all, we may pose the following question: "Does the law interfere with the freedom of regulation of obligatory relations or the so-called "autonomy of will" (article 3 of the Obligation Relations Act ${ }^{19}$ )? Namely, trade participants freely regulate obligatory relations in accordance with the Constitution, laws and good practices. In accordance with the aforesaid, participants in obligatory relations freely determine the time of fulfilling their obligations. If the time limit is not

12 Article 1 of the Act amending the Promissory Note Act, Official Gazette of RM, 12/2014

13 Article 17 of the Promissory Note Act or article 274-a of the Criminal Act

14 According to Article 4, there is insolvency when the economic operator is more than 30 days delayed with fulfilling one or more financial obligations.

15 According to Article 5, there is insolvency when economic operator: 1) becomes incapable of payment, and 2) becomes over-indebted.

16 Article 7 of the Extrajudicial Settlement Act

17 As determined by Article 4, paragraph 1, point 3 of this Act

18 Definition is given in Article 4, paragraph 1, point 2 of this Act

19 Official Gazette of RM, 18/2001 
determined and the purpose of the business operation, the nature of obligation and other circumstances do not require certain fulfillment term, the creditor can require immediate obligation fulfillment, and the debtor can require immediate acceptance of fulfillment by the creditor ${ }^{20}$. Anyway, obligation may be fulfilled before the expiry of the time limit. On the other hand, Articles 5 and 6 of the Financial Discipline Act provides precise terms for fulfilling financial obligations. It is clear that the freedom of regulating obligatory relations is not absolute but it ranges within certain wider and narrower limits. Yet, those limits should be determined by the legislator objectively, on the basis of specific conditions of living in a community, the level of economic development and other criteria (Chavdar, Kl., Chavdar, Ko., 2012, 16). This gives rise to the question concerning the compliance of the law with the Constitution of the Republic of Macedonia, especially with Article 55 which guaranties the freedom of market and entrepreneurship.

In addition, there was a problem interpreting the definition of "business transaction". Namely, a conclusion cannot be drawn from the definition whether business transaction is the same as contract, or it is something else. We believe that it would be proper if business transaction is understood as a set of individual goods deliveries, provision of services and performance of works, which further implies that every single delivery of individual goods or provision of services shall be governed by the same terms stipulated by the law.

Additionally, the definition of "business transaction" and other legal provisions do not determine whether the law will be implemented in situations when one of the contracting parties is a foreign legal entity. Considering the definitions of terms, it is clear that this Act does not include situations when one of the business partners is a foreign legal entity or a sole proprietor. The Financial Discipline Act will be also valid for contracts concluded between a Macedonian and a foreign subject, if the parties invoke the Macedonian law as an authoritative law for regulating their relations, i.e. if the specific obligation is to be fulfilled by the contracting party with residence in Macedonia (Pro Agens, 2014).

One of the provisions which have created issues in practice is Article 5 paragraph 2 of this Act, which enumerates several circumstances when the deadline for fulfilling the financial obligations starts to be valid. It is also disputable how the participants in a business transaction will precisely determine when the debtor had received the invoice or other request for fulfilling a financial obligation. Additionally, aren't these rules overlapping? The problem is even more aggravated taking into consideration the fact that the debtor is not obliged to sign, seal and date the receipt of invoice ${ }^{21}$. Another disputable issue is when the creditor will be considered

20 Article 303 of the Obligation Relations Act of RM., Official Gazette of RM, 18/01

21 Article 53, paragraph 10 of the Act on Value Added Tax, Official Gazette of RM, 44/99 
to have fulfilled the obligation, i.e. delivered the agreed goods, service or work. We believe that subjects in business transactions (the creditor or the debtor alike) will have to introduce a more efficient process of issuing and receiving invoices which is supposed to overlap with the time of delivery of the agreed goods, services or works. Additionally, for the purpose of determining the moment of invoice receipt and confirming the goods delivery, service or work, it is advisable that the invoices be accompanied by delivery notes including the signature or/ and stamp as well as the receipt date. Also, it is also essential to create more efficient mechanisms for return and correction of disputable invoices or other financial documents; namely, it should be made obligatory that those documents are accompanied by a written letter providing notice that they are being returned and that they do not impose any financial obligation upon the debtor, who would thus avoid the consequences stipulated in the Financial Discipline Act.

It is expected that there will be numerous cases in practice where the creditors will fulfill their obligation ( i.e deliver the agreed goods, service or work) but they will be overdue in sending the invoice to the debtor who will not be able to pay the financial obligation within the specific term. In those cases, we believe that the debtor will have to insist on timely invoice delivery by the creditor. Also, there will be situations when the invoice date will be have been issued well before the creditor's obligation fulfillment date; consequently, it will not be clear when the debtor has received the invoice and when the creditor has fulfilled the obligation. The previous situation is even more complicated when the invoice is even more delayed, i.e. bearing an older date of invoicing, as a result of which the debtor cannot determine with certainty when the date of the creditor's obligation fulfillment. These situations have to be resolved by giving more latitude to the delivery notes in trade, which have to include the signature, the delivery date, the receipt of delivery notes and (if possible) appropriate corrections of invoicing dates.

On the other hand, in cases involving a dispute between parties for acknowledgment of debt, the provisions of the Financial Discipline Act remain to be applied under the specific circumstances. This is particularly problematic taking into consideration Article 12 of the Financial Discipline Act, which stipulates a notification to the Public Revenue Office (PRO) which is entitled to determine whether the provisions of this Act have been violated by the private sector economic operator even in cases where the creditor files a suit to the authorized court or proposal for payment order to a notary. In this context, the following question arises: How can the PRO determine whether the provisions of this Act have been violated if the debtor in that payment order procedure complains against the notary decision by negating the existence of legal grounds and providing relevant to that effect, in which case it is the court that has the final decision?! 
Probably the most problematic provision by far is the provision in Article 5 paragraph 3 of the FDA, which stipulates a possibility for fulfilling the financial obligation within a term longer than 60 days but not longer than 120 days, providing that there is an explicit written consent by both parties. Firstly, the determination of a maximum term for fulfilling the financial obligations is disputable, especially with regard to the fact that the FDA stipulates certain consequences for the violation of those terms, even though such approach is not typical for many other countries. Such flexibility is also determined by the Directive 2011/7/EU, which states that member-states will regulate the payment term by contract $^{22}$ ensuring that it does not exceed 60 calendar days, unless otherwise stipulated in the contract and providing that it is not quite unfair towards the creditor, within the explanation of Article $7^{23}$ which stipulates unfair contracting terms and practices. Further on, it is not clear what kind of exceptions would avoid the consequences stipulated in the Act, i.e. ungrounded payment of fines (on the one hand) or avoiding of circumvention of transaction creditors (on the other hand). Thirdly, the meaning of "explicit written consent by both parties" is not specified, and it is unclear whether it refers to a contract, agreement or something else?! We believe that justification of these exceptions should be found in the established trade practice between retailers as well as in the need to preserve contracts in mutual interest of the contracting parties.

Regarding the explicit written consent, it is most acceptable to conclude contracts or agreements expressing good will by both parties in the business relation and stipulating a term longer than 60 days for financial obligations fulfillment. Thereby, it should not be forgotten that contracts for delivery of goods, for example, are not formal contracts, which means that a mandatory written form is not prescribed for them in the Obligation Relations Act. Accordingly, it may be wrongly concluded that the Financial Discipline Act introduces a mandatory written form for contracts in these relations. Certainly, when agreeing on the term longer than 60 days for fulfilling financial obligations, it is possible to accept some form of explicit written consent. The written form of such contracts should be understood only as a way of providing larger legal safety for contracting parties rather than a legal obligation.

In this part, the following question arises: "Is an explicit written consent necessary for each individual business transaction (i.e. for every single individual goods delivery, provision of service or performance of work), or is it sufficient to provide such written consent once between the same contracting parties in a business relation? We believe that it would be an excessive burden on trade if such explicit written consent was to be provided between the contracting parties for each individual

22 It refers to the private sector economic operators.

23 Article 3 (5) of the Directive 2011/7/EU 
business transaction, even though it is in accordance with the definition given in the FDA. In that context, when the same business subjects have an intention to agree a term longer than 60 days for fulfilling the financial obligations in a certain business relation, they are recommended to provide only one written consent which will cover all individual business transactions arising from their relation. Still, Article 7 of the FDA should be taken into consideration; in case the payment term is not determined in the financial transaction or when contracts include nullity provision regarding payment term, Article 7 provides that the debtor shall fulfill the financial obligations within 30 days. According to the aforesaid, if contracting parties have an intention to agree a term longer than 30 days and shorter than 60 days for the fulfillment of financial obligations fulfillment, it is advisable to note their will in some written form given the fact that the 30 days term of payment will otherwise be valid, regardless of the fact that the subjects had the intention to agree on a 45 days term. Yet, it is still disputable how to interpret the meaning of determining a time limit in business transaction as provided in Article 7 of the FDA! Does it mean that the due payment date (in this case 30 to 60 days term) can be determined in the invoice or in some "other appropriate payment request"? In our opinion, a term longer than 30 days and shorter than 60 days can be determined in the invoice or "other appropriate payment request" bearing no obligation to create a written contract, agreement, etc.

Yet, taking into consideration the previously stated reasons, it may be expected that the application of various written forms for continuation of terms over 60 days will be a frequent practice in the Republic of Macedonia. It is also expected that debtors will make efforts to prolong the financial obligations payment within the terms specified in the FDA even though they formerly may have performed their obligations in relatively shorter terms. Generally speaking, it could be reasonably said that terms for fulfilling financial obligations in a business relation will depend on the negotiating power of each subject.

Article 6 of the FDA stipulates the terms for fulfillment of financial obligations when the debtor is a public sector subject. Paragraph 2 of this Article, which is considered to be problematic, provides that the payment term in multiannual public procurement contract may be longer than 60 days, but it does not stipulate the maximum term for fulfilling the financial obligation. It is unclear why a financial obligations fulfillment term is not determined in case of multiannual public procurement contracts, particularly taking into consideration Article 26-a paragraph 1 of the Public Procurement Act ${ }^{24}$, which states: "(1) Before initiating the procedure for concluding multiannual public procurement contract, the contracting body is obliged to plan the assets necessary for their budget realization, investment program or by financial plan for the respective year."

24 Official Gazette of RM, 136/2007 
Moreover, Article 8 of the FDA does not clearly determine how the compensation for delay will be charged when the debtor has a obligation to fulfill the financial obligation in the amount of 3.000 denars, in what kind of procedure and by what kind of request?! The payment of this compensation is most likely to be effected by filing a claim for payment order or lawsuit. Article 9 of the FDA is fully controversial as it is contrary to the Obligation Relations Act. Namely, as the FDA envisages the payment of certain amount of interest as penalty for the failure to fulfill financial obligations within the specified term, the origin of the provision it unclear particularly considering the provision in Article 266, paragraph 1 of the Obligation Relations Act (ORA) which stipulates that: "In addition to the principal, the Debtor who is overdue in performing his financial obligations is also obliged to pay a penalty interest." Additionally, Article 313, paragraph 1 of the ORA states: "The debtor is in delay if he has not fulfilled the obligation within the specified term for fulfillment." (more: Chavdar, Kl., Chavdar, Ko., 2012, 6).

Article 12 of the FDA raise the following question, which is particularly disputable in practice: In case the debtor has not fulfilled the financial obligation within the terms stipulated by this Act, does the private sector economic operator (creditor) have an obligation to file a lawsuit with a competent court, a proposal for execution to an executor, or a proposal for payment order to a notary?! At this point, it should be noted that the FDA does not stipulate a mandatory obligation for the creditor to file a suit with an competent court, a proposal for execution to an executor or a proposal for payment order to a notary.

Article 14 of the FDA is especially problematic as it stipulates as follows: "If the Financial inspection in the public sector and the Public Revenue Office determine any breach of this Act in the course of their regular or extraordinary control, they are entitled to initiate an infringement proceeding." In this context, it must be clarified that according to this Act only the debtor bears a misdemeanor liability. However, taking into consideration the previous provision, it is necessary to emphasize that the supervisory bodies may also initiate a misdemeanor proceeding against the debtor in cases where they determine during their control that the debtor has breached the FDA. This provision enables the supervisory bodies to institute a misdemeanor proceeding in situations when they have recorded a violation of the FDA, regardless of whether the creditor has filed a lawsuit with a competent court, a proposal for execution to an executor or a proposal for payment order to a notary.

As for Article 17 of the FDA, there is a general opinion that the amount of fine is not correlated either with the amount of the financial obligation or with the size of the business entity. It is also worth mentioning that fine is prescribed only in case of not fulfilling the obligations within the terms stipulated in the FDA; 
therefore, if the subject does not perform the obligation within the given term, it may result in initiating a misdemeanor proceeding. This may imply that, given the absence of a written contract whereby the parties have explicitly expressed their will to agree on a term longer than 60 days, or when 30 to 60 days term has not been specifically determined as previously stated, the debtor may bear misdemeanor liability for exceeding the legal terms governing the fulfillment of financial obligations.

\section{Conclusion}

The Financial Discipline Act has been applied since $1^{\text {st }}$ May 2014. During this short application period, subjects in business transactions have encountered multiple problems and the negative effects of the FDA application are expected to be even more prominent in the future. This legislative act must not restrict the freedom of agreement and, on a larger scale, it must be in compliance with the content of the Directive 2011/7/EU. Whereas this paper cannot answer all the questions posed by the application of this Act, there is an obligation to actively observe its implementation, analyze the effects of the Financial Discipline Act and, relying on those findings, establish a further approach to this issue.

\section{Bibliography}

Chavdar, Kl., Chavdar, Ko. (2012). Law on obligations. Comments, explanations, practice and material register. Skopje: Akademik

Chavdar, Kl., Chavdar, Ko. (2014). Notes for correlations of terms in the Law on financial discipline and Law on obligations. Counseling regarding the law on financial discipline, Skopje, 30.01.2014. 1-9

Shafranko, Z. (2012). Kritički osvrt na provedbu Direktive 2011/7/EU u hrvatsko pravo - drugi dio: suzbijanje zakašnjelih plaćanja i zloporabe ugovorne autonomije na štetu vjerovnika. Pravo u gospodarstvu, vol. 51, 5. 1227-1250

Directive 2011/7/eu on combating late payment in commercial transactions of 16 February 2011, Official Journal of the European Union L 48/1

Euro Chambres. Late Payment Directive six month on public payments still much too slow. Преузето 30.01.2014. http://www.30max.eu/map-of-debtors/

Law on financial discipline, Off. Gazette of RM, 187/2013

Zakon o rokovima izmirenja novcanih obaveza u komercijalnim transakcijama, Sluzbeni glasnik R.Srbije, 119/2012 
National Bank of RM. (2013). Report for financial stability in the Republic of Macedonia in 2012

National Bank of RM. (2014). Report for financial stability in the Republic of Macedonia in 2013

Pro Agens. (2014). Practical implications from the implementation of new Law on financial discipline. Guide of Law on financial discipline and VAT updates. [Electronic version]. Downloaded 01.11.2014. http//www.proagens.mk

\title{
Мр Орде Ѓорѓиоски
}

\section{ЗАКОНОДАВСТВО О СПРЕЧАВАЫУ КАСНОГ ПЛАТАЫА У РЕПУБЛИЦИ МАКЕДОНИЈИ И ПРЕПОРУКЕ ЗА ДЕЛОВАЊЕ ПРИВРЕДНИХ СУБЈЕКАТА}

\begin{abstract}
Резиме
Циљ овог рада је анализа новог Закона о финансијској дисциплини Републике Македоније, који је ступио на снагу 1. маја 2014. године, и степена усклађености овог закона са Директивом 2011/7/ЕУ о спречавању касног плаћања у пословним трансакцијама. На основу идентификованих недостака овог закона, аутор указуја на неопхоност доношења бољих законских решења у оквиру националног законодавства о спречавању касног плаћања доспелих обавеза у пословним трансакцијама. Поред примене новог законодавства којим се регулише касно плаћање доспелих обавеза у пословним транскацијама, аутор наглашава потребу да се у регулисању облигационих односа странкама гарантује принцип слободе договарања, тј. такозвани принщип аутономије воље. У Републици Македонији често нема довољно флексибилности у регулисању рокова за испуњење финансијских обавеза. Принцип аутономије воље угрожава се покретањем поступака о финансијској дисциплини, упркос чињеници да основни циљ овог закона није заштита субјеката из јавног сектора већ заштита привредних субјеката, првенствено малих и средњих предузећа. У том контексту, настојање аутора да спроведе детаљно истраживање на ову тему је више него оправдано с обзиром да се ради о релативно новом начину регулисања рокова за испуњење финансијских обавеза у пословним трансакцијама, који је садржан у законодавству Европске уније као и у националим законодавствима држава које настоје да постану чланище Европске уније.
\end{abstract}

Кључне речи: финансијска дисциплина, трансакција, касно плађање, аутономија воље, рокови. 